\title{
EchoGéo
}

23 | 2013

Entre l'ancien et le nouveau monde. La transcendance du lieu et de l'espace en géographie vinicole contemporaine

\section{Assessing vulnerability and framing adaptive options of two Mediterranean wine growing regions facing climate change: Roussillon (France) and McLaren Vale (Australia)}

Anne-Laure Lereboullet, Douglas Bardsley et Gérard Beltrando

\section{(2) OpenEdition}

Édition électronique

URL : https://journals.openedition.org/echogeo/13384

DOI : 10.4000/echogeo.13384

ISSN : 1963-1197

Éditeur

Pôle de recherche pour l'organisation et la diffusion de l'information géographique (CNRS UMR 8586)

Référence électronique

Anne-Laure Lereboullet, Douglas Bardsley et Gérard Beltrando, « Assessing vulnerability and framing adaptive options of two Mediterranean wine growing regions facing climate change: Roussillon (France) and McLaren Vale (Australia) », EchoGéo [En ligne], 23 | 2013, mis en ligne le 05 juin 2013 consulté le 10 août 2021. URL : http://journals.openedition.org/echogeo/13384 ; DOI : https://doi.org/ 10.4000/echogeo.13384

Ce document a été généré automatiquement le 10 août 2021.

EchoGéo est mis à disposition selon les termes de la licence Creative Commons Attribution - Pas d'Utilisation Commerciale - Pas de Modification 4.0 International (CC BY-NC-ND) 


\section{Assessing vulnerability and framing adaptive options of two Mediterranean wine growing regions facing climate change: Roussillon (France) and McLaren Vale (Australia)}

Anne-Laure Lereboullet, Douglas Bardsley et Gérard Beltrando

\section{Introduction: The importance of climate change for Mediterranean viticulture}

1 The wine industry is particularly sensitive to variations in climate, whether in relation to intra-annual variability (vintage effect) or in long term trends (terroir characterisation). Producers are used to deal with the effects of inter-annual climate variability and changes in consumers' demand. However, long term changes could require deeper structural changes than variability, especially when combined to a globalization of markets that make economic trends more complex.

Many wine producing regions, both in the old World and the New World, are situated in areas with a Mediterranean climate, where an optimal amount of insolation, heat and water is typically available for the growth of Vitis Vinifera. However, it is projected that climate change in those regions is likely to occur in the form of increasing temperatures and decreasing rainfall (IPCC, 2007). While a warmer and drier climate might be generally profitable in some cool wine producing regions (Madelin et al., 2010; Briche, 2012 in France; Webb et al., 2007 in Australia), many drier Mediterranean areas are already situated at the hotter margins of Vitis vinifera's optimal growth range (Jones et al., 2005). Where wine producers in such areas are aiming to develop premium grapes 
and wines to survive world competition, and to exploit a strong regional identity as a comparative advantage, climate change-induced shifts in quality may be particularly problematic. In fact, the Allen Consulting Group (2005) suggested that farming systems cumulating the three following characteristics would be most at risk from climate change: systems that are already stressed economically or biophysically, systems at the edge of their climate tolerance, and systems where large and long lived investments are made such as in dedicated irrigation systems, perennial crops and processing facilities. Based on these characteristics, viticultural systems situated in drier Mediterranean climatic areas could be particularly at risk in the future. It is thus essential for farmers and key stakeholders to understand now the extent of risk for regional systems, and build adaptive capacity in preparation for future change.

\section{A socio-ecological comparative approach}

3 Adaptive capacity refers to the ability of a system to prepare for those changes in advance as well as to adjust and respond to the impacts of the changes (Smit et al., 2006; Engle, 2011). Milestad et al. (2012) add the notion of uncertainty to this definition: "the adaptive capacity of a farming system refers to its ability to perform well according to unknown future boundary conditions, unprecedented occurrence of perturbations including severe crisis and goals that might change over time due to endogenous or exogenous reasons". The weaker is the adaptive capacity of a given system, the lower is its critical change tolerance threshold. It is thus important for a regional wine industry to increase its adaptive capacity, in order to manage a range of potential changes, while allowing for flexibility to correct adaptive trajectories if approaches prove unsustainable at a later date. In other words, viticultural systems need to be both efficient to deal with the regular challenges of sustainable production systems, and flexible and adaptive to environmental change (Dedieu, 2009; Darnhofer 2010).

4 Adaptive capacity mitigates risk by modulating its key component, vulnerability. The IPCC (2007) illustrates vulnerability through three concepts, which we can model as followed:

Vulnerability $=$ (exposure $x$ sensitivity $)$ - adaptive capacity

First, it defines exposure as the extent to which a system is physically in harm's way. Second, sensitivity refers to how affected a system would be after exposure to the stress (Smit et al., 2006; Adger et al., 2007; Engle 2011). Vulnerability is thus determined by both biophysical and socio-economic aspects, combined with the incapacity to (re)act. For example, in the context of severe drought in a viticultural area, a vulnerability assessment might include the magnitude of the drought itself, biophysical factors (soil, varieties grown, vineyard and winery management techniques), economic factors (types of wine produced, competition in the market place, impact on producer's income), or social factors (competition for and legislation regulating water resources, community support or insurance).

The present study focuses on assessing the vulnerability of Mediterranean viticulture to changes in climate and frame ways to increase its adaptive capacity. It compares two wine producing regions, with a relatively similar Mediterranean climate but different socio-economic components: Côtes-du-Roussillon-Villages in France and McLaren Vale in Australia. The systemic differences that alter the vulnerability of both systems will be discussed. In order to produce useful recommendations for farmers, it is important 
to study jointly the magnitude of changes and the way changes are managed within a farming system (Lee, 1999). The study is thus built around four objectives: (i) assessing the systems' past, current and future exposure to climate change, (ii) assessing their sensitivity to such exposure, (iii) determining their key vulnerability issues, and (iv) assessing their current adaptive capacity and frame possible options to increase it over the coming decades. We use an integrative and mixed-methods approach, taking into account the multiplicity of elements intertwined with climate to understand changes in yields, quality of harvest, income and the future of the industry. It combines secondary data from climate stations to assess exposure to changes in temperature and rainfall, and primary data from interviews to assess how producers perceive changes in climate, what impacts they have on grape growing and wine making, and what types of adaptive options they have recently implemented or consider implementing in the near future. We believe that looking at the capacity to adapt to climate change is a good indication of the general flexibility and sustainability of a viticultural system facing change. Importantly, findings from Mediterranean viticulture may provide important lessons that are applicable to other wine regions and other farming systems as environmental and economic pressures increase.

\section{Field sites choice and description}

6 In France, viticultural activity in the area of Côtes-du-Roussillon-Villages (lat: $42.8^{\circ} \mathrm{N}$, long: $2.8^{\circ} \mathrm{E}$ ) was examined (illustration 1 ). Grape production is situated in two hilly corridors a few kilometers north-east of the city of Perpignan, bounded to the south by the Têt valley and the north by the Corbières karst region. It corresponds to the northern part of the administrative boundary of département des Pyrénées-Orientales, in the region Languedoc-Roussillon, and to the Appellation d'Origine Contrôlée (AOC, Controlled Origin Appellation) of "Côtes-du-Roussillon-Villages". It is abbreviated to "Roussillon" in the present article. In Australia, McLaren Vale (lat: $35.2^{\circ} \mathrm{S}$, long: $138.5^{\circ} \mathrm{E}$ ) is situated in South Australia, approximately $35 \mathrm{~km}$ south of the city of Adelaide. It is bounded to the west by the waters of Gulf St Vincent, to the north-east by the Adelaide Hills range and to the south-east by the Sellicks Hill range. Much of the area is devoted to viticulture, at an altitude ranging from approximately $100 \mathrm{~m}$ to the west to $320 \mathrm{~m}$ to the east. The average size of a vineyard is 4.1 hectares in Roussillon (Onivins, 2011) and 13.9 hectares in McLaren Vale (ABS, 2009-10). Both GI regions' size approximate $400 \mathrm{~km}^{2}$ and they share a similar Mediterranean climate characterized by irregular autumn or winter rain and dry summers. They belong to the CSb climate type ("hot summer" or "typical" Mediterranean climate) of Köppen-Geiger classification (Peel $e t$ al., 2007), and both benefit from cooling maritime influence and rarely experience frost. The strong northerly dry wind, Tramontane, blows regularly in Roussillon, ventilating the vines and thus reducing cryptogamic diseases, but also drying them out during heat waves and damaging young growth in spring. In McLaren Vale, strong, hot, dry Northerly breezes are experienced, but sea breezes from Gulf St-Vincent in spring and 'gully winds' in summer can cool down the vineyards. 
Illustration 1 - Situation map

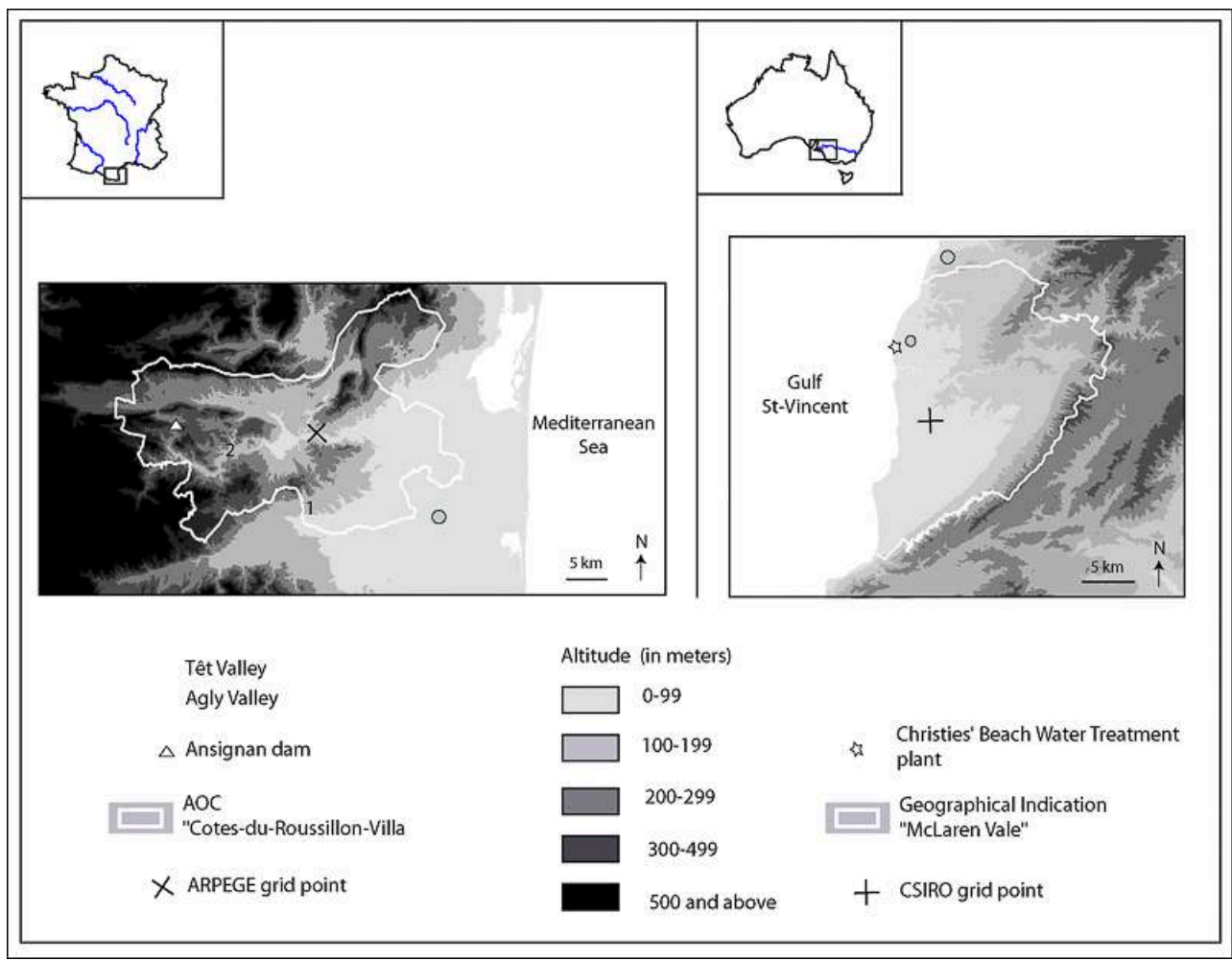

Sources: Institut Géographique National and Phylloxera and Grape Indutry Board of South Australia.

\section{Exposure to an uncertain hotter and drier climate (1956-2060)}

7 In order to assess exposure to climate change in the recent past and the near future up to 2060 , we used different climate data sets. We focused on change affecting temperature and precipitation, which are essential climate parameters to understand grapevine growth and maturation (Dry and Coombe, 2004). We used the emission scenario A1B, considered as moderate (IPCC, 2007). Table 1 details the characteristics of each dataset.

Table 1 - Climate data parameters used to assess past and future exposure to climate change (1956-2060) in Roussillon and McLaren Vale

\begin{tabular}{|c|c|c|}
\hline Data parameters & Roussillon & McLaren Vale \\
\hline \multicolumn{3}{|l|}{ Observed Data } \\
\hline Station name & Perpignan (CNRM) & $\begin{array}{l}\text { Adelaide airport (ABM) and Noarlunga } \\
\text { (ABM) }\end{array}$ \\
\hline Station position & $42.4^{\circ} \mathrm{N}, 2.9^{\circ} \mathrm{E}$ & $34.9^{\circ} \mathrm{S}, 138.5^{\circ} \mathrm{E}$ and \\
\hline Time series & $1956-2010$ & $1956-2010$ and 2002-2011 \\
\hline
\end{tabular}




\begin{tabular}{|c|c|c|}
\hline Climate parameters & Daily TX, TN and PP & Daily TX, TN and PP \\
\hline \multicolumn{3}{|l|}{ Simulated data } \\
\hline Model name & $\begin{array}{l}\text { QQ-ARPEGE-RETIC V4 } \\
\text { Meteo-France, } 2011\end{array}$ & $\begin{array}{l}\text { CSIRO Mk3.5 } \\
\text { (Gordon et al, 2010) }\end{array}$ \\
\hline Spatial resolution & $8 \mathrm{~km}$ & $0.25^{\circ}(\sim 25 \mathrm{~km})$ \\
\hline $\begin{array}{l}\text { Grid point centre } \\
\text { coordinates }\end{array}$ & $42.8^{\circ} \mathrm{N}, 2.8^{\circ} \mathrm{E}$ & $35.2^{\circ} \mathrm{S}, 138.5^{\circ} \mathrm{E}$ \\
\hline Time series & $\begin{array}{l}\text { 2001-2060, } \\
\text { continuous }\end{array}$ & 2020-2060, 5-year average \\
\hline Emission scenarios & $\mathrm{A} 2, \mathrm{~A} 1 \mathrm{~B}$ and $\mathrm{B} 1$ & A1B \\
\hline Climate parameters & Daily TN, TX and PP & Monthly TN, TX and PP \\
\hline
\end{tabular}

CNRM = Centre National de la Recherche Météorologique, $\mathrm{ABM}=$ Australian Bureau of Meteorology. $\mathrm{TX}=$ maximum temperature, $\mathrm{TN}=$ minimum temperature, $\mathrm{PP}=$ precipitations

8 Illustrations $2 \mathrm{a}$ and $2 \mathrm{~b}$ show the observed and simulated evolution of minimum and maximum temperature during the growing season, which is conventionally limited from April to October in the northern hemisphere, and from October to April in the southern hemisphere.

Illustration 2a - Observed and simulated evolution of minimum and maximum air temperature during the growing season, from 1956 to 2060, in Roussillon

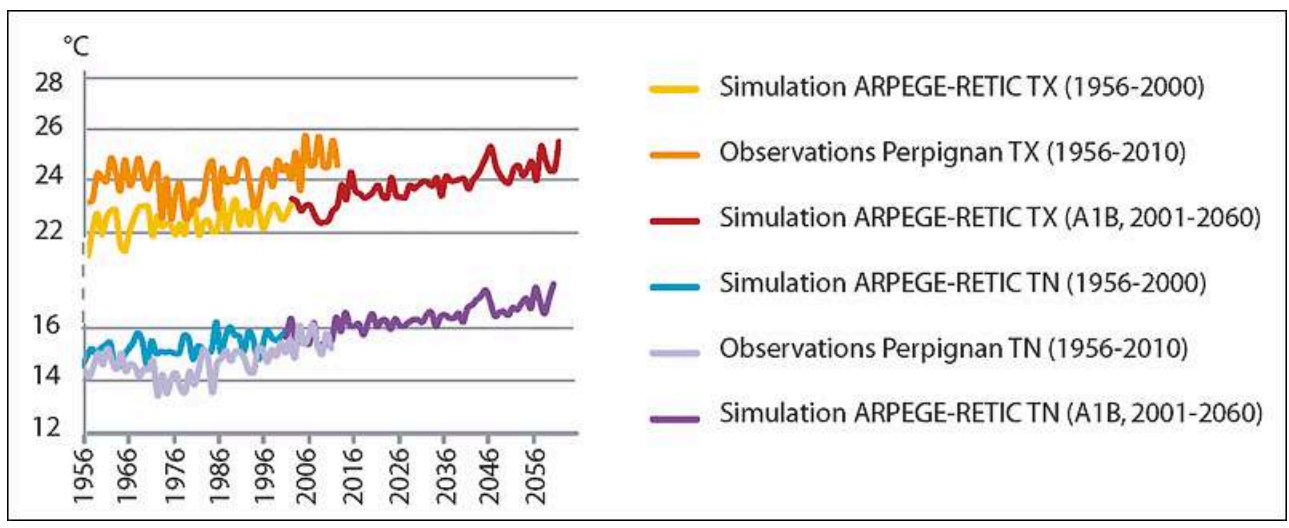

Sources: CNRM and ABM/CSIRO. 
Illustration $2 b$ - Observed and simulated evolution of minimum and maximum air temperature during the growing season, from 1956 to 2060, in McLaren Vale

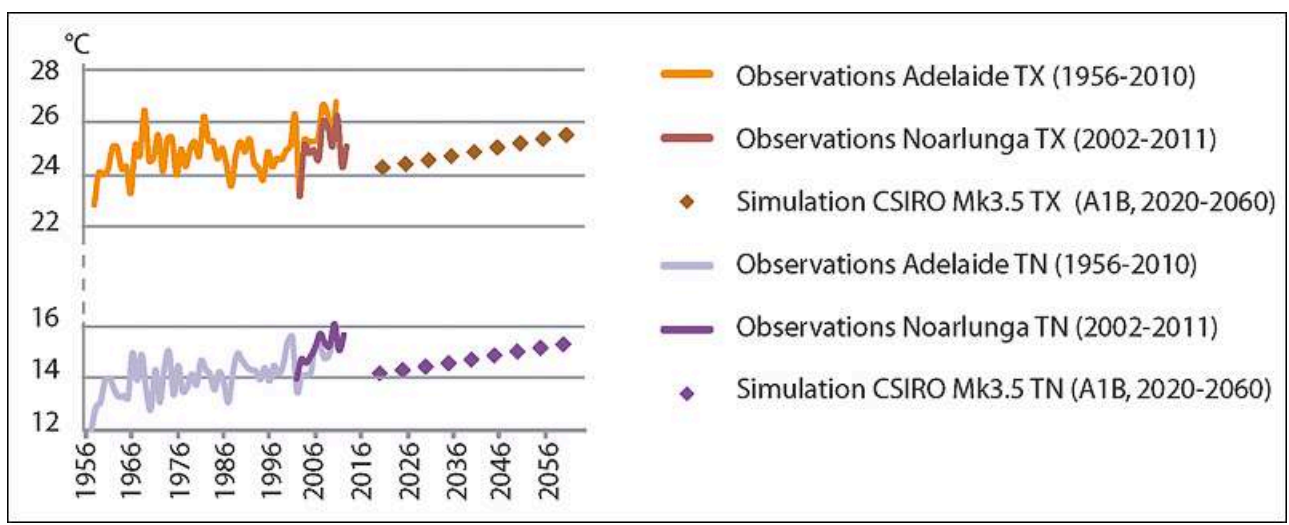

Sources: CNRM and ABM/CSIRO.

Three important comments can be drawn from these data. Firstly, minimum and maximum temperatures have been continuously increasing in Perpignan and Adelaide since the 1980's. The 2001-2010 decade was on average $0.8^{\circ} \mathrm{C}$ hotter than the $1961-1970$ decade in both stations. Secondly, simulations project a general trend of increasing temperatures. In Roussillon, a fastest increase is apparent from the 2040's onwards, which means it will hit the next one or two generations of producers. On average, as simulated by models, the $2051-2060$ decade is $1^{\circ} \mathrm{C}$ hotter than the 2021-2030 decade in Roussillon, and $0.9^{\circ} \mathrm{C}$ in McLaren Vale. However, uncertainty remains regarding the precise quantification and variability of this pattern of change. Comparisons between the model control series and observations in Roussillon, and between observations in Noarlunga and simulations with a grid point centred on Noarlunga in McLaren Vale, show that both models present a cold bias, and thus a potential underestimation of regional warming.

Illustration 3a - Observed and simulated evolution of precipitation in non-summer months, from 1956 to 2060 , in Roussillon

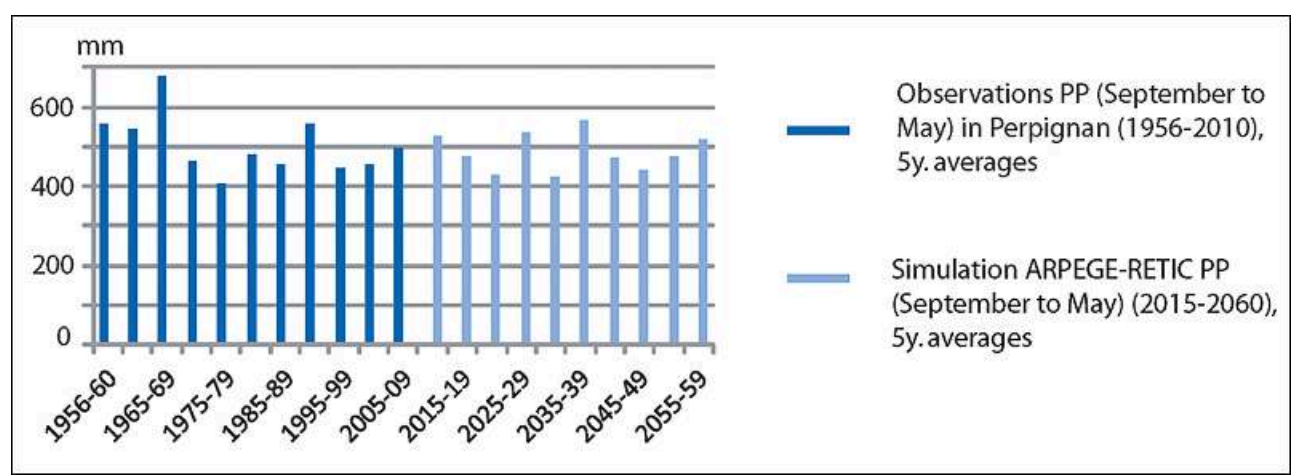

Sources: CNRM and ABM/CSIRO. 
Illustration 3b- Observed and simulated evolution of precipitation in non-summer months, from 1956 to 2060, in McLaren Vale

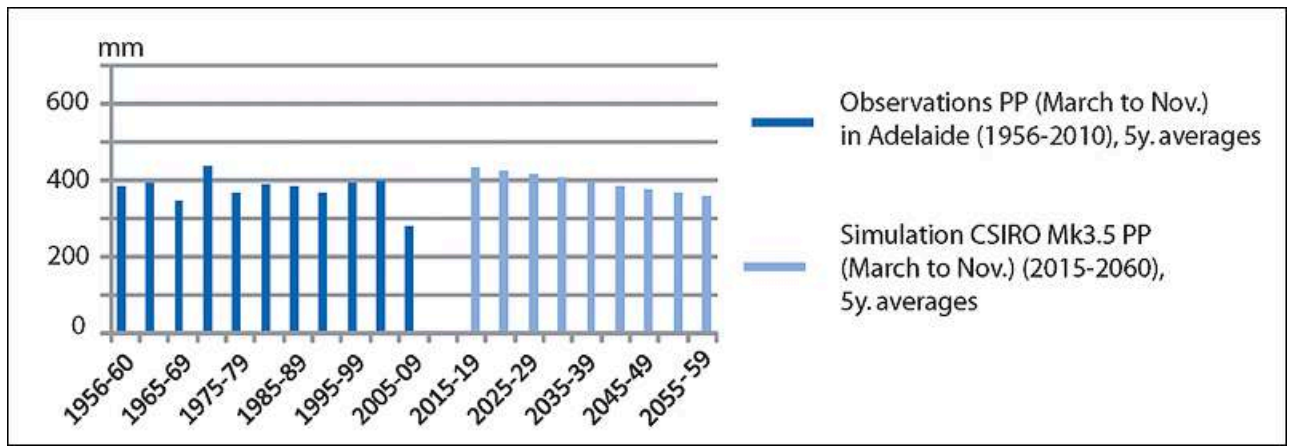

Sources: CNRM and ABM/CSIRO.

Illustration 3c-Observed and simulated evolution of precipitation in summer months, from 1956 to 2060, in Roussillon

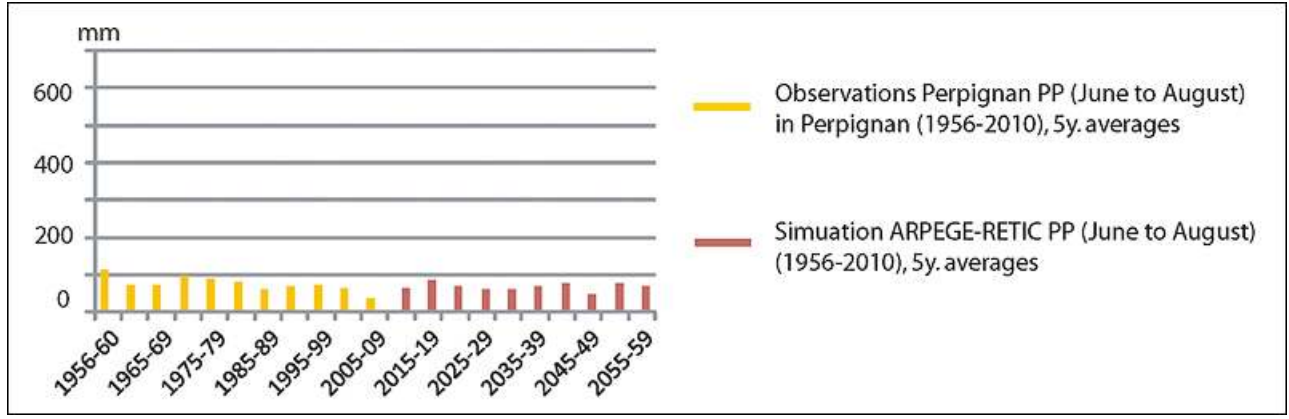

Sources: CNRM and ABM/CSIRO.

Illustration 3d - Observed and simulated evolution of precipitation in and summer months, from 1956 to 2060, in McLaren Vale

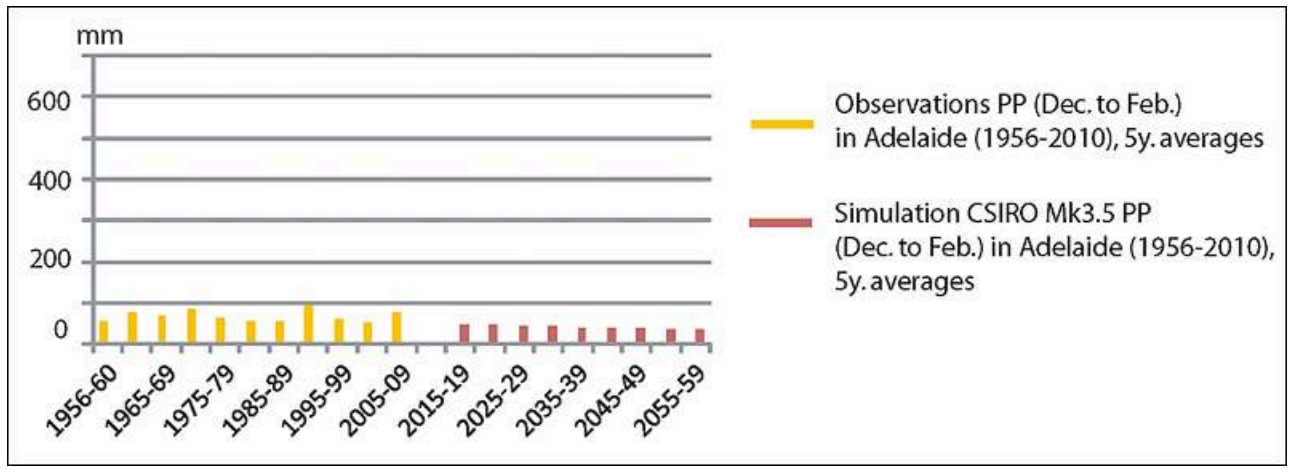

Sources: CNRM and ABM/CSIRO.

10 Illustrations $3 \mathrm{a}$ to $3 \mathrm{~d}$ show the observed and simulated evolutions of precipitations over the year. In Mediterranean climates, rainfall and aquifer recharge occur mainly in Fall and Winter. However, a small amount of summer rainfall is also important to help grapevines carry out maturation and avoid leaf loss, especially during hot summers (Gladstones, 2012). Rainfall is naturally variable inter-annually and spatially in those climates and very low in summer, thus it is difficult for models to simulate past and future rainfall accurately, especially extremes. Even if a great deal of uncertainty 
remains on future rainfall in both regions, two points can be stressed: in Roussillon, from 2015-2019 onwards, summers are projected to be drier than during the 1956-1999 period; and in McLaren Vale, both summer and non-summer rainfall follow a linear trend of decrease with all summers from 2015-2019 onwards drier than during the 1956-1999 period. In the recent past, the period 2005-2009 was particularly dry (low summer rainfall in Perpignan, low non-summer rainfall in Adelaide with two major droughts in 2008 and 2009).

11 Climate results show that growing seasons are most likely to be hotter and drier on average compared to the climate of the second half of the XXth century. In other words, the climate experienced during the dry decade of the 2000's could become the norm until the 2040's. However, recognizing the uncertainties of atmosphere-ocean general and regional circulation models is important when using them as a primary basis to develop policies dealing with the impacts they project. Rather than adapting to a single future, the biggest challenge for producers in Roussillon and McLaren Vale is to be able to adapt to an uncertain future in climate, in which hotter and drier conditions are likely to be more common.

\section{Cumulative and complex impacts on the two viticultural systems}

12 Impacts of and adaptation to changes in temperature and rainfall in the last ten years give a foretaste of what is awaiting the two regional industries. This was assessed through in-depth interviews with key stakeholders: thirty-two (twenty-nine producers) in Roussillon in May and October 2011 and June 2012 and thirty (twenty-two producers) in McLaren Vale in July 2011 and July 2012. A majority of stakeholders interviewed were both grape growers and wine producers, which allowed for insights into both processes, and others were members of governance bodies or representatives of the industry. We chose interviewees with the aim to obtain a sample of various types of estates in location, size, history and cultural methods, in order to develop a data set that is qualitatively representative of the region. Interviews were conducted face-toface, except in Roussillon where half of the interviews were conducted over the phone for practical reasons. They followed the same semi-structured approach with questions dealing with characteristics of the property, perceived challenges to the activity (past, present and future exposure and sensitivity), current and planned future practice, and factors that encourage or limit changes in practice. In addition, producers were presented with basic regional climate models outputs for future climate change and asked how they thought that change would impact on their activities, and if or how they would adapt to it. The questionnaire included both closed and open-ended questions, as well as Lickert scales measuring how producers perceive climatic and economic factors as limitations to adaptation. Crossing farm and business characteristics with occurrences of specific answers in closed questions and/or key words in open-ended questions allowed for identifications of key factors in adaptive capacity and for framing different types of producers based on their capacity to adapt in the past, the present and near future.

13 An increase in day and night temperatures during the growing season leads to interrelated agro-ecological consequences, including an earlier and shorter growing season and various impacts on berry maturation. This has been documented in many 
wine producing regions over the world (White et al., 2006; Schultz and Jones, 2010; Briche, 2012) and was evident in interviewees' responses from both regions. A major consequence for producers is that grapevine growth and maturation occurs not only in a hotter climate generally, but also earlier in the season and thus the key growth period of maturation occurs in the warmer period of the year. Illustration 4 summarizes the different negative consequences due to a hotter and drier climate spontaneously mentioned by producers, in percentage of completed interviews.

Illustration 4 - Percentage of producers spontaneously mentioning in interviews the following negative impacts of warmer temperatures and drought on berry maturation, in Roussillon and McLaren Vale

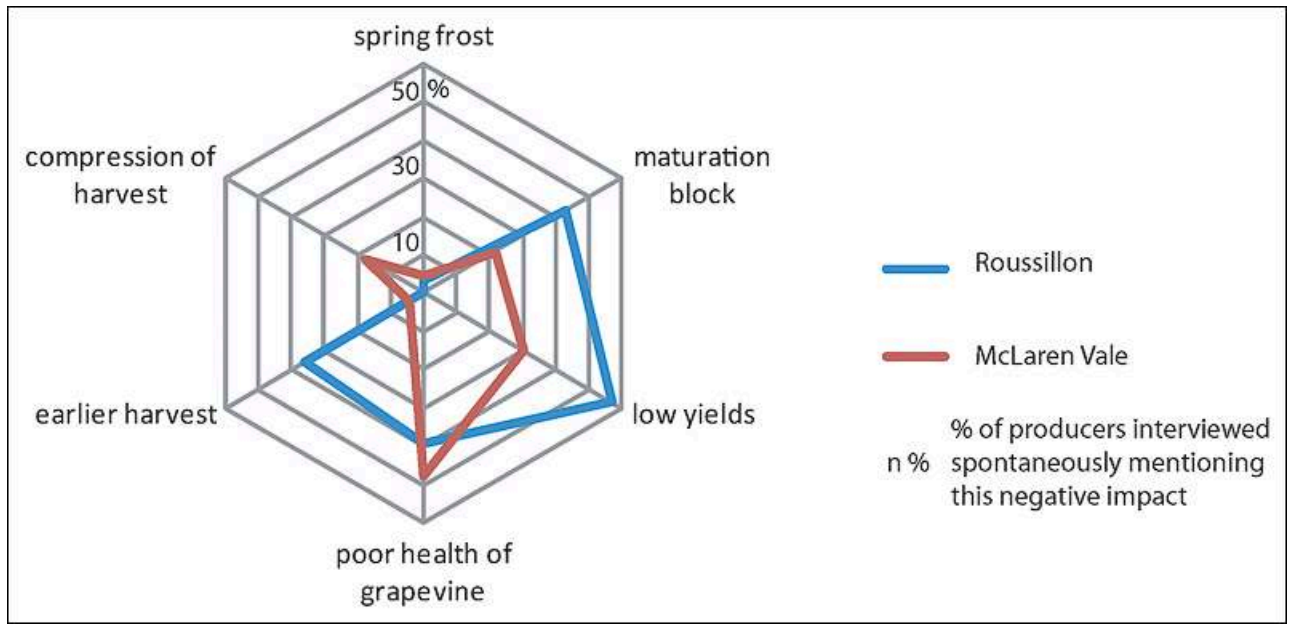

Observed decreases in yields and blocks in maturation are particularly important in Roussillon, where the majority of vineyards are dry-grown. In Roussillon, AOC regulations impose a maximum yield of $45 \mathrm{hL} / \mathrm{ha}$. However, in the last decade, this maximum was not reached by a majority of producers and many were unable to maintain profitable systems. Between 2000 and 2009, average yields were of $27 \mathrm{hL} / \mathrm{ha}$ in the department of Pyrénées-Orientales, compared to 38 for Languedoc-Roussillon and 50 for France (Onivins, 2011). Drought appears to be playing an important role here (Payan et al. 2011). In fact, three climatic effects are accumulating. Firstly, higher temperatures lead to an accelerated phenological cycle and thus to a mechanical decrease of yields. Secondly, a decrease in summer rainfall impacts on grapevine vigour and berry weight, especially on soils with a low water holding capacity. A decrease in winter and spring rainfall limits aquifer recharge and causes early drying out of soils that can negatively impact on berry size. Thirdly, the accumulative effects of increasing temperatures and decreasing rainfall lead to higher evapotranspiration rates, and thus higher water consumption by grapevine cultivars displaying near-anisohydric properties such as Shiraz (Syrah) (Schultz, 2003; Soar et al., 2006). It has been estimated that with current management, yields in Languedoc-Roussillon could decrease by $26 \%$ by 2080 due to increased water stress (Garcia de Cortazar, 2006). In addition, quality problems arise when the cumulative effect of high temperatures and acute water stress lead to a mismatch between sugar accumulation and decrease of tannins, and thus to a high alcohol content in wine (Dry and Coombe, 2004). Traditional vineyard management, such as canopy management, weeding and pruning, have proved insufficient in the last ten years to deal with drier and hotter conditions. 
Problems in yields and maturation were less reported among Australian interviewees, thanks to the existence of a reliable irrigation system in McLaren Vale. Efficient dripirrigation systems have become widespread since the 1990's, mainly in order to maintain constant yields and wine styles and grow grapes on soils not naturally suited for viticulture (such as heavy clays). This practice plays a significant buffering role to deal with hot and dry weather conditions. Indeed, Shiraz, which represents $80 \%$ of plantings in McLaren Vale, can maintain yields in response to a 2 to $4^{\circ} \mathrm{C}$ increase in air temperature, given it is irrigated (Sadras and Soar, 2009), while the increase projected by models by 2060 is up to $2^{\circ} \mathrm{C}$. In 1999, an irrigation system was implemented using reclaimed water from Adelaide coastal suburbs after filtration at the Christies' Beach water treatment plant (illustration 1), which satisfies a great majority of producers. The average connection fee for producers is \$AUS18 000 (11 000 Euros), to which an annual fee per surface unit is added depending on distance and topography. Producers consider the investment as a comparative asset that adds to the value of their properties. Even though agricultural policy in Australia has seen the state minimize direct involvement in agricultural markets, federal subsidies did provide a $50 \%$ rebate for growers willing to connect to the system, between 2009 and 2012. According to producer $n^{\circ} 31$, in McLaren Vale, "Climate change won't be a problem as long as we have access to enough water."

\section{Key sensitivity and vulnerability issues}

The drip-irrigation system from recycled water in McLaren Vale is a good example of an innovative technique, complementary to traditional vineyard management practices, which allows for a better consistency of wine quality in hotter and drier years. However, several issues prevent producers from sustainably implementing innovative techniques in both regions.

One key issue for both regions is accessing sufficient financial capital to enable leeway for producers to take risks and implement change. In Roussillon, this issue is particularly acute, because in comparison to McLaren Vale, many producers are in a difficult economic situation. The region has been undergoing tremendous quantitative and qualitative restructuring in the last thirty years. Changes in market preferences have forced producers to switch from fortified and high yielding table dry wines to premium dry wines. As a result, between 2002 and 2010, 40\% of vineyards in surface were pulled out in Pyrénées-Orientales. The cooperative system, developed in the 1930 's, still has an important social role. Even though the number of cooperatives dropped from 64 in 1996 to 48 in 2006, 71.5\% of vineyards by surface area were still harvested through them in 2006 (Onivins, 2011). In the department's biggest cooperative, the average payment is 2400 Euros per hectare per year, while members of the cooperative typically only have six to eight hectares. With such a low income from viticulture, the potential to try out new strategies is greatly diminished. An irrigation project has been on-going since 2010 using water from the Ansignan dam to irrigate 80 ha of vineyards down the Agly valley. Theoretically, irrigation could allow gains of 10 to $20 \mathrm{hL} / \mathrm{ha}$ in yield and thus more producers would reach the maximum authorized yields more regularly and balance their income between higher-producing and lowerproducing blocks. The projected cost for producers is 400-450 Euros/hectare, under the condition the project gets subsidies from the European Union, which still represents an 
important investment for a typical producer. The poor economic health of the regional wine industry also leads to a lack of sufficient incentive for producers to implement change. In McLaren Vale, the financial capital issue takes the form of a high dependency on exports. Many producers have recently either significantly reduced their exports or lowered prices, due to the high Australian dollar, and this has impacted their incomes directly.

Alongside an increase in temperature and a decrease in water availability for grapevines, arises the issue of water resources management. The urbanization and tourist development of the coastal area has also increased pressure on water resources, a common issue in many Mediterranean coastal areas (Aunay et al. 2006, Ghiotti and Riviere-Honegger 2009; Iglesias et al. 2009 in the Western Mediterranean basin; Bardsley and Sweeney 2008, Connor et al. 2009, Head et al. 2011 in Australia). Thus the projected decrease in rainfall could make competition more acute between actors to access water resources, especially in Roussillon, where fruit culture is mainly irrigated with rivers water. However, the cultural acceptance of implementing any irrigation system to produce a premium wine is limited by the fact that a flood-irrigation system in the region helped to produce high-yielding but poor-quality fruit up until the 1970's. In McLaren Vale, the recycled water scheme has diminished competition to access water resources. However, the levels of water salinity were reported by interviewees as an important concern, especially those who use water from private bores. In contrast to rain water, irrigation water contains dissolved salts and deficit-irrigated vineyards are at risk from salinization, which limits grapevine growth, productivity and fruit quality (Downtown and Loveys, 1978; Shani et al., 1993). Thus, a major concern for irrigated vineyards in arid and semi-arid regions could be, rather than the increase in temperatures per se, increasing drought and salinity of soils due to higher evaporation coupled with declining water availability (Stevens and Walker, 2002; Keller, 2010).

Regulations such as AOCs and GIs aim at building an identity for a wine producing region, providing consumers with a consistent level of quality and style for labelled products. Identity building is valuable at the regional and individual level, given it provides visibility in a highly competitive market. To be labelled with a GI "McLaren Vale", wines must be produced from at least $85 \%$ of grapes grown in McLaren Vale. In France, AOC Côtes-du-Roussillon-Villages is much more restrictive, as it imposes blending of at least two varieties among four allowed (Grenache, Carignan, Syrah, Mourvedre), and all must be grown in the defined area. Syrah was imposed in the 1970 's as a cepage ameliorateur to increase the quality of regional red wines. It now represents 53\% of plantings in Pyrénées-Orientales (Onivins, 2011). However, in comparison to other Mediterranean varieties, Syrah is particularly sensitive to water stress and the strong winds that blow regularly in Roussillon. Some producers mentioned their wish to decrease their surfaces planted to Syrah, partly due to the climatic factors. Table 2 summarizes the major vulnerability issues to climate change in both regions.

Table 2 - Key vulnerability issues to climate change in Roussillon and Mclaren Vale

\begin{tabular}{|l|l|l|}
\hline & Roussillon (FR) & McLaren Valle (AUS) \\
\hline
\end{tabular}




\begin{tabular}{|c|c|c|}
\hline Economic issues & $\begin{array}{l}\text { - Access to financial } \\
\text { capital } \\
\text { - Competition with other } \\
\text { regions } \\
\text { - Lack of economic } \\
\text { incentive }\end{array}$ & $\begin{array}{l}\text { - Dependency on exports } \\
\text { Competition with other regions } \\
\text { - Overproduction }\end{array}$ \\
\hline $\begin{array}{l}\text { Environmental } \\
\text { issues }\end{array}$ & $\begin{array}{l}\text { - Competition for water } \\
\text { resources }\end{array}$ & - Salinity problems \\
\hline $\begin{array}{l}\text { Socio-cultural } \\
\text { issues }\end{array}$ & $\begin{array}{l}\text { - Cultural rejection of } \\
\text { irrigation } \\
\text { - AOC regulations of } \\
\text { plantings }\end{array}$ & $\begin{array}{l}\text { - Tension between intra-regional } \\
\text { cooperation and competition }\end{array}$ \\
\hline
\end{tabular}

\section{How to increase adaptive capacity?}

Due to uncertainty in both climatic and economic futures, the two viticultural systems must try to: (i) decrease sensitivity to the key issues mentioned and (ii) increase their general adaptive capacity towards different kinds of changes. As well as being flexible and reactive, in order to respond to systemic stresses, some adaptation planning will need to guide new development directions for both regions. Two key adaptive themes emerged from interviews: diversity and entrepreneurship.

Firstly, adaptive capacity depends on the ability to spread risks and create buffers to sudden changes in both the climate and economy. This was largely acknowledged by producers interviewed and has been observed for other farming systems (Bardsley, 2003). Interviewees whose businesses appeared to be less vulnerable to climate change were not always the wealthiest, but rather those who were diversifying in several respects and had financial leeway to implement change. Diversification can take place at different levels of the viticultural system. For instance, a producer in Roussillon describes his activity in those words: 'For forty years I had several activities. I was in the military, I grew apricots, I grow grapes from which I make and sell wine. Since the beginning, I have used various retail networks such as restaurants, shops, supermarkets and cellar door to sell my wine, visited wine fairs in France and Northern Europe, sold wine in various formats (bottles and bag-in-box). I have stopped growing apricots in 2009 because spring frost risk associated with warm peaks in early spring was too risky, and growing both apricots and grapes was too time and energy consuming. Climate is changing and if it continues like that we will be forced to adapt. It is a matter of good sense not to put all your eggs in the same basket.' Based on results from interviews, table 3 synthesizes the different diversification options available to producers in both regions.

Table 3 - Synthesis of diversification pathways avalaible to producer in Roussillon and McLaren Vale

\begin{tabular}{|l|l|}
\hline Diversification pathway & Comments \\
\hline $\begin{array}{l}\text { Various grape sourcing (different blocks } \\
\text { in the same or different regions) }\end{array}$ & Limited in Roussillon due to AOC regulations \\
\hline
\end{tabular}




\begin{tabular}{|l|l|}
\hline Variety in production chain & $\begin{array}{l}\text { Both growing and processing grapes or producing } \\
\text { other crops }\end{array}$ \\
\hline Products on offer & $\begin{array}{l}\text { Need to find a balance between different levels of } \\
\text { quality of wine, and the regional identity advertised }\end{array}$ \\
\hline Various retail networks & $\begin{array}{l}\text { Need to balance production for domestic and } \\
\text { international markets }\end{array}$ \\
\hline Pluri-activity of households & $\begin{array}{l}\text { Maintain off-farm employment when possible, } \\
\text { especially near urban centers }\end{array}$ \\
\hline Tourism & $\begin{array}{l}\text { Farm visits and wine tastings require a regional uptake } \\
\text { of tourism promotion }\end{array}$ \\
\hline
\end{tabular}

Secondly, it appears from interviews that individual entrepreneurship plays a crucial role in the implementation of new adaptive strategies. Based on studies from Couzy and Docks (2008), Battaglini et al. (2009) and Milestad et al. (2012), adaptive farmers are those who have already adapted and wish to adapt further; are creative; and, develop a hybrid development path between continuity of the traditional farming model and the creation of a personal business. There is growing evidence both in Roussillon and McLaren Vale that the uptake of innovation and personal strategies is important to maintain and grow a competitive grape growing and wine selling business. The persistence of traditional farming techniques, which have proved relatively efficient until now, could limit producers' abilities to innovate, especially if they underestimate the environmental changes to come.

We identified four types of producers within the two regions covering all producers interviewed, based on their diversification and entrepreneurship levels (table 4). Criteria to differentiate a "diversified producer" from a "non-diversified" were the existence of two or more of the following: both growing grapes and making wine, both member of a cooperative and individual producer, two or more styles of wine produced (red, white, rosé, dry, fortified), two or more levels of grapes and/or wine produced (AOC or GI, lower quality labels, no label), grapes sourced from more than one region. An "entrepreneur producer" had accomplished at least one of the following: implementation of change in cultural and/or commercial practices over the last five years and/or next five years, establishment of activity since ten years or less.

Table 4 - Characteristics of four types of producers, classified in numbers in an ascending order according to their general adaptive capacity

\begin{tabular}{|l|l|}
\hline Type 1: non-diverse and non entrepreneur & $\begin{array}{r}\text { Type 2:diverse but non-entrepreneur } \\
\text { • Decreasing }\end{array}$ \\
$\begin{array}{l}\text { - Mraditionalists } \\
\text { - Weak perception of change }\end{array}$ & $\begin{array}{l}\text { - Diversity sustained rather than carefully planned } \\
\text { - Medium adaptive capacity to changes in market }\end{array}$ \\
\hline
\end{tabular}




\begin{tabular}{|l|l}
\hline Type 3: non diverse but entrepreneur & Type 4: diverse and entrepreneur \\
• Moderately increasing & - Increasing \\
• Strong perception of change & - Strong perception of change \\
- Capacity to implement change & - Growing business
\end{tabular}

Type 1 is predominant among grape growers that solely depend on a cooperative in Roussillon or long-term contracts with wineries in McLaren Vale. Producers that fit this category are usually close to retirement and thus with little incentive to change. Their perception of long-term trends of change is generally weak. In general, their adaptive capacity is weak and this type of farmers is decreasing in number in both regions. For instance, producer $\mathrm{n}^{\circ} 51$, in Roussillon grows red and white grapes processed through one cooperative. She does not believe there are long-term changes in climate. She does not plan to invest in irrigation, as she grows mainly Muscat for fortified wines, and is close to retirement. She only worries for what she thinks she can change, and climate is not part of it.

Type 2 producers are traditionally diverse, usually because they come from a longestablished business, but their lack of innovation is the expression of a strong confidence in existing adaptive techniques, coupled to a weak perception of change and/or a lack of financial capital to implement change.

Type 3 are usually specialized producers who have not yet exploited potential benefits of diversifying their sources of income within the grape and wine business. However, their capacity to implement change is an asset for their general adaptive capacity.

Type 4 is predominant among producers who sustain both grape growing and wine making and selling activities. They could be represented by dynamic producers and cooperatives in Roussillon and big wineries in McLaren Vale. These producers are the most resilient to changes in climate and the economy. For instance, producer $n^{\circ} 40$ in Roussillon is less than thirty years old, and cultivates 36 ha of various red and white varieties, to make dry and fortified wines. He is much concerned about a less regular and predictable climate in the future, changes that he has already observed. He converted to organic viticulture three years ago, but will go back to conventional if it is not profitable. During the next three years, he plans to mechanize the whole vineyard to decrease operational costs.

It will be essential for producers to find a balance between operational costs and benefits from diversification and new management practices. For instance, Belliveau et al. (2006), in a study about wine production in the Okanagan Valley in Canada, showed that adaptation to market can be contradictory with adaptation to climate change in terms of grape varietal choice. Producers from McLaren Vale have experienced this dilemma over the last thirty years, when Chardonnay was very popular on the domestic market, but requires high levels of irrigation. When production costs grew higher than benefits, producers gradually turned away from the variety. In general, adaptation to economic incentives with no account for climate change has proved unsustainable, such as in the Murray-Darling Basin (Van Dijk et al., 2007). Likewise, adaptation strategies designed for climate change with no regard to social and economic constraints at the farm level are most likely to be unsuccessful (Petheram et al., 2010; Eakin and Patt, 2011). As stated by producer $n^{\circ} 23$, in McLaren Vale: "For sure, irrigation 
wise, I would plant only Grenache on my property. But who would buy it? The market for Grenache is not big enough to absorb too much of it!"

\section{Conclusion}

This study showed that both Roussillon and McLaren Vale have been recently negatively affected by a succession of hot and dry years, and that climate simulations project a continuation of such changes as a long-term trend through to 2060. However, the level of uncertainty remains great in the precise quantification and variability of changes in temperature and rainfall. At the same time, structural changes in the economy, such as the globalisation of the wine market, have added pressures on Mediterranean viticultural systems. Interviews showed that the major elements of systems strongly influence the abilities of producers to implement change from within and to increase their adaptive capacity. For example, precise drip-irrigation in McLaren Vale offers an opportunity to buffer the effects of hot and dry years on yields, wine quality and wine style. It is a strong comparative asset within a region aiming to produce consistent premium wines. However, this example of adaptive strategy might not be replicable on a large scale in Roussillon, due to a combination of water accessibility and quality issues, strong regional traditions, a complex system of regulations and a lack of financial capital.

The implication of actors at both the individual and collective levels appears to be an essential key to increase adaptive capacity. The emergence of some key regional actors, particularly diverse, dynamic and innovative, can help implement change and improve the health of the regional system. This can be done upstream, by transmitting innovation vertically from wineries to growers, or allowing scale economies in French cooperatives; and downstream, by promoting the regional identity on markets to boost sales and thus income. This takes into account the role of state organizations. For instance, the AOC system is helpful for producers if it is clear that it should not replace wines with less prestigious appellations that are more flexible and adaptive to international markets. Similarly, the Chambre d'Agriculture in Roussillon is efficient in building adaptive capacity when it provides producers with tools without supplanting individual entrepreneurship.

The present study would not have been possible without the financial support of the Wine 2030 funding scheme, as well as the support of: in Australia, the McLaren Vale Grape Wine and Tourism Association, the Phylloxera Grape Industry Board of South Australia and the Bureau of Meteorology; in France, of the Chambre d'Agriculture des Pyrénées-Orientales and Meteo-France. The authors would also like to acknowledge the help during the interview process of Eric Rouvellac (University of Limoges, France) in Roussillon, Alexandra Blandis and Chelsea Wilson in McLaren Vale. 


\section{BIBLIOGRAPHIE}

ABS (Australian Bureau of Statistics), 2010. Vineyard Estimates, Australia, 2009-10. October 2010.

Adger W.N., 2006. Vulnerability. Global Environmental Change, 16, 3, p. 268-281

Aunay B., Dorfliger N., Duvail C., Grelot F., Le Strat P., Montginoul M., Rinaudo J.D., 2006. Hydrosocio-economic implications for water management strategies: the case of Roussillon coastal aquifer. Colloque international sur la gestion des grands aquifères, Association Internationale des Hydrogéologues, Dijon, France. Available at : http://hal-brgm.archives-ouvertes.fr/docs/ 00/46/80/31/PDF/MO2006-PUB00020237.pdf

Bardsley D.K.. 2003. Risk alleviation via in situ agrobiodiversity conservation: drawing from experiences in Switzerland, Turkey and Nepal. Agriculture, Ecosystems \& Environment, 99, p. $149-157$.

Bardsley D.K., Sweeney S., 2008. A Regional Climate Change Decision Framework for Natural Resource Management. South Australian Government Report through the Department of Water, Land and Biodiversity Conservation, Adelaide. Available at: www.garnautreview.org.au/

Battaglini A., Barbeau G., Bindi M., Badeck F.W., 2009. European winegrowers' perceptions of climate change impact and options for adaptation. Reg. Environ. Change, 9, p. 61-73.

Briche E., 2012. Changement climatique dans le vignoble de Champagne : Modélisation thermique à plusieurs échelles spatio-temporelles (1950-2010). PhD thesis, Université Paris-Diderot, 307 p.

Connor J., Schwabe K., King D.,Kaczan D., 2009. Impacts of Reduced Water Availability on Lower Murray Irrigation, Australia. The Australian Journal of Agricultural and Resource Economics, 53, p. 433-452.

Couzy C., Docke A.C., 2008. Are farmers businesspeople? Highlighting transformations in the profession of farmers in France. Int. J. Entrpreneurship and Small Business, 6, 3, p. 407-420.

Darnhoffer I., 2010. Strategies of family farms to strengthen their resilience. Environmental Policy \& Governance, 20, p. 212-222.

Dedieu B., 2009. Qualification of the adaptive capacities of livestock living systems. Revista Brasileira de Zootechnica, 38, p. 397-404.

Downtown W., Loveys B., 1978. Compositional change during grape berry development in relation to abscisic acid and salinity. Australian Journal of Plant Physiology, 5, p. 415-423.

Dry P.R., Coombe B.G. (Eds.), 2004. Viticulture, Volume 2: Practices, $2^{\text {nd }}$ ed. Adelaide, Australia, Winetitles.

Engle N.L., 2011. Adaptive capacity and its assessment. Global Environmental Change, 21, p. 647-656. Garcia de Cortazar, I., 2006. Adaptation of crop model STICS to the grapevine (Vitis vinifera L.). Use for an impact study of the climatic change on the scale of France. PhD Thesis. INRA Montpellier. Available at: http://www.inra.fr/ea/EA_these/?action=4\&these $=200$

Ghiotti S., Rivière-Honegger A., 2009. Eaux sous pression et développement des territoires périurbains en Méditerranée occidentale (Languedoc-Roussillon). La vigne, le Sphaeromide raymondi et les piscines. Norois, 211, 2, p. 37-52. 
Gordon H., O'Farrell S., Collier M., Dix M., Rotstayn L., Kowalczyk E., Hirst T., Watterson I. (2010) The CSIRO Mk3.5 Model. CAWCR Technical report n 021, CSIRO. Available online at: http:// www.cawcr.gov.au/publications/technicalreports/CTR_021.pdf

Head L., Atchison J., Gates A., Muir P., 2011. A fine-grained study of the experience of drought, risk and climate change among Australian wheat farming households. Annals of the Association of American Geographers. DOI: 10.1080/00045608.2011.579533.

Iglesias A., Cancelliere A., Cubillo F., Garrote L., Wilhite D.A., 2009. Coping with drought risk in agriculture and water supply systems: Drought management and policy development in the Mediterranean. Springer, The Netherlands.

IPCC, 2007. Fourth Assessment Report: Climate Change. Available online at: www.ipcc.ch Jones G.V., White M.A., Cooper O.R., Storchmann K., 2005. Climate change and global wine quality. Climatic Change, 73, p. 319-343.

Keller M., 2010. Managing grapevines to optimise fruit development in a challenging environment: A climate change primer for viticulturists. Australian Journal of Grape and wine Research, 16 (Suppl. 1), p. 56-69.

Lee K.N., 1999. Appraising adaptive management. Conservation Ecology, 3, 3.

Madelin M., Bois B., Chabin J.P., 2010. Modification des conditions de maturation du raisin en Bourgogne viticole liée au réchauffement climatique. EchoGéo [En ligne], $14 \mid 2010$, mis en ligne le 13 décembre 2010. URL : http://echogeo.revues.org/12176 ; DOI : 10.4000/echogeo.12176.

Meteo-France, 2011. Description des données mises à disposition dans DRIAS. Available online at: http://publitheque.meteo.fr/Docs/drias/pdf/Point2_Description_Donnees_DRIAS_JL.pdf

Onivins, 2011. Statistical publications from FranceAgriMer, French Ministry of Agriculture. Available at: http://www.onivins.fr

Payan I.C., Salançon E., Genevet B., Jacquet O., 2011. Les effets de l'irrigation au vignoble. Publication of IFV, available at: http://www.vignevin-lr.com/fileadmin/users/ifv-lr/videos/EVVLR2011/ $\mathrm{PdM} /$ IrrigationPayan.pdf

Peel M.C, Finlayson B.L., McMahon T.A., 2007. Updated world map of the Köppen-Geiger climate classification. Hydrol. Earth Syst. Sci., 11, p. 1633-1644.

Sadras V.O., Soar C.J., 2009. Shiraz vines maintain yields in response to a $2-4^{\circ} \mathrm{C}$ increase in maximum temperature using an open-top heating system at key phenostages. European Journal of Agronomy 31, p. 250-258.

Schultz H.R., 2003. Differences in hydraulic architecture account for near-isohydric and anisohydric behaviour of two field-grown Vitis vinifera L. cultivars during drought. Plant Cell and Environment, 26, p. 1393-1405.

Schultz H.R., Jones G.V., 2010. Climate induced historic and future changes in viticulture. Journal of Wine Research, 21, 2-3, p. 137-145.

Shani U, Weisel Y, Eschel A, Xue S, Ziv G, 1993. Responses to salinity of grapevine plants with split root systems. New Phytologist, 124, p. 695-701.

Smit B., Wandel J., 2006. Adaptation, adaptive capacity and vulnerability. Global Environmental Change 16, 3, p. 282-292.

Soar C.J., Speirs J., Maffei S.M., Penrose A.B., McCarthy M.G., Lovey B.R., 2006. Grape vine varieties Shiraz and Grenache differ in their stomatal response to VPD: apparent links with ABA 
physiology and gene expression in leaf tissue. Australian Journal of Grape and Wine Research, 12, p. 2-12.

Stevens, R, Walker, R, 2002. Response of grapevines to irrigation-induced saline-sodic soil conditions. Australian Journal of Experimental Agriculture, 42, p. 323-33.

The Allen Consulting Group, 2005. Climate Change Risk and Vulnerability: Promoting an efficient adaptation response in Australia. Australian Greenhouse Office, Department of the Environment and Heritage, Canberra.

Van Dijk A., Podger G., Kirby J.M., 2007. Integrated water resources management in the MurrayDarling Basin: increasing demands on decreasing supplies. In Marino, MA and Simonovic, S (Eds). Integrated Water Resources Management, IAHS Publication, IAHS, p. 24-30.

Webb L.B., Whetton P.H., Barlow E.W.R., 2007. Modelled impact of future climate change on the phenology of winegrapes in Australia. Australian Journal of Grape and Wine Research 13, p. 165-175.

White M.A., Diffenbaugh N., Jones G.V., Pal S., Giorgi F., 2006. Extreme heat reduces and shifts United States premium wine production in the $21^{\text {st }}$ century. Proceedings of the National Academy of Sciences of the United States of America, 103, 30, p. 11217-11222.

\section{RÉSUMÉS}

Une hausse des températures et une baisse des précipitations pourraient être préjudiciables au maintien d'une viticulture de qualité dans les régions de climat méditerranéen. Cet article propose d'étudier l'exposition récente et future de deux régions viticoles méditerranéennes à de tels changements : le Roussillon (France) et McLaren Vale (Australie); ainsi que de cerner les éléments concourant à augmenter leur vulnérabilité face à ces changements, et en retour les éléments qui permettraient d'améliorer leur capacité d'adaptation. Une étude de données de température et de précipitations observées (1956-2010) à Perpignan et Adelaïde, et simulées (2001-2060) par ARPEGE-RETIC-V4 et CSIRO Mk3.5, a été complétée par soixante-et-un entretiens avec des acteurs-clés de la filière viti-vinicole dans les deux régions. Les résultats montrent que les producteurs ont dû faire face ces dix dernières années à une augmentation de la température et à une baisse des précipitations, et que cela est, selon les modèles, amené à se répéter d'ici 2060, malgré une grande part d'incertitude. Ces conditions ont des impacts négatifs sur la maturation du raisin, qui ne pourront pas forcement être gérés avec les techniques actuelles. La mise en place de stratégies d'adaptation à l'incertitude du climat, couplées à celle des marchés, s'appuie sur : un capital financier suffisant, une gestion durable des ressources en eau, et une souplesse de la législation. Pour cela, la diversification et l'entreprenariat des producteurs sont particulièrement importants.

An increase in temperatures and a decrease in precipitations could be prejudicial to maintaining a premium wine production in regions with a Mediterranean climate. The present article offers to assess recent and future exposure to such changes in two Mediterranean wine producing regions: Roussillon (France) and McLaren Vale (Australia); as well as to frame elements increasing their vulnerability to such changes, and reversely elements that could help increase their adaptive capacity. A study of temperature and rainfall data observed (1956-2010) in Perpignan and Adelaide and simulated (2001-2060) by ARPEGE-RETIC-V4 and CSIRO Mk3.5 was completed by sixty-one interviews with key stakeholders of the wine industry in both regions. Results show that producers had to face an increase in temperature and a decrease in rainfall in the last decade, and this tendency, according to climate models, is likely to continue through to 2060 , with a fair level of uncertainty. This has negative impacts on grape maturation, and 
traditional vineyard management may not be sufficient to deal with it in the long term. Implementing new strategies of adaptation to uncertainty in climate, as well as in economy, depends on: a sufficient financial capital, a sustainable management of water resources, and flexibility in legislation. To achieve this, diversification and entrepreneurship of producers is particularly important.

\section{INDEX}

Mots-clés : viticulture, climat méditerranéen, changement climatique, vulnérabilité, adaptation Keywords : viticulture, Mediterranean climate, climate change, vulnerability, adaptation Thèmes : Sur le Champ - Sur le Terrain

\section{AUTEURS}

\section{ANNE-LAURE LEREBOULLET}

Anne-Laure Lereboullet, anne-laure.lereboullet@etu.univ-paris-diderot.fr, is PhD student in Geography at Université Paris-Diderot, Paris, France. She recently published :

- Lereboullet A.-L., Beltrando G., Bardsley D.K. and Rouvellac E., In Press. The viticultural system and climate change: coping with long-term trends in temperature and rainfall in Roussillon, France. Regional Environmental Change. DOI 10.1007/s10113-013-0446-2.

- Lereboullet A.-L., Beltrando G. and Bardsley D.K., 2013. Socio-ecological adaptation to climate change: A comparative case study from the Mediterranean wine industry in France and Australia. Agriculture, Ecosystems and Environment, 164, p. 273-28.

- Lereboullet A.-L., Beltrando G., Bardsley D.K., Rouvellac, E., 2012. Le changement climatique va-t-il déstabiliser la filière viti-vinicole dans le Roussillon? Actes du XXV eolloque de l'Association Internationale de Climatologie, Grenoble, 5-7 septembre 2012.

\section{DOUGLAS BARDSLEY}

Douglas Bardsley, : douglas.bardsley@adelaide.edu.au, is Senior lecturer at Adelaide University, Adelaide, Australia. He recently published:

- Bardsley D.K., Wiseman N.D., 2012. Climate change vulnerability and social development for remote indigenous communities of South Australia. Global Environmental Change, 22, p. 713-723. - Bardsley D.K., Pech P., 2012. Defining spaces of resilience within the neoliberal paradigm: Could French land use classifications guide support for risk management within an Australian regional context? Human Ecology, 40, p. 129-143.

- Bardsley D.K., Rogers G.P., 2011. Prioritizing engagement for sustainable adaptation to climate change: An example from natural resource management in South Australia. Society and Natural Resource, 24, p. 1-17.

\section{GÉRARD BELTRANDO}

Gérard Beltrando, beltrando@univ-paris-diderot.fr, is Professor of Climatology, Université ParisDiderot, Paris, France. He recently published:

- Dahech S., Beltrando G., 2012. Observed temperature evolution in the City of Sfax (Middle Eastern Tunisia) for the period 1950-2000. Climatic Change, 114, p. 689-706.

- Bisci C., Fazzini M., Beltrando G., Cardillo A., Romeo V., 2012. The February 2012 exceptional snowfall along the Adriatic side of Central Italy, Meteorologische Zeitschrift, 21, 5, DOI 
10.1127/0941-2948/2012/0377.

- Beltrando G., 2012. Elévation du niveau marin dans les îles intertropicales des océans Pacifique et Indien : responsabilité du changement climatique et des autres actions de l'Homme. Territoire en movement, 14-15, p. 120-137. 